\title{
Sir Donald MacAlister, of Tarbert, Baronet.
}

Donald MacAlister was born in Perth on May 17 , 1854 . His school education began in Aberdeen and concluded at the Liverpool Institute. His school successes were phenomenal: he gained every prize he entered for, was first in all England in the Oxford Senior Local Examinations, won half a dozen gold and silver medals, and when he left school gained simultaneously scholarships at Balliol and Worcester Colleges in Oxford, and St John's College, Cambridge. He elected to go to Cambridge, and there, in 1876 , he was awarded the Sir John Herschel Prize for Astronomy, and in 1877 was Senior Wrangler and First Smith's Prizeman, and was elected to a Fellowship at St John's. After a term at Harrow as mathematical master, MacAlister turned to medicine, as he had always intended to do. He spent two years studying at St Bartholomew's Hospital, acting at the same time as Lecturer on Natural Philosophy. Survivors of those who were then students have testified to his extraordinary powers as a lecturer, and to his capacity for making things clear even to those possessed of only a rudimentary knowledge of mathematics.

In 1880 he graduated B.Sc., London, and M.B., Cambridge, and spent eight months of the following year working with Professor Ludwig in Leipzig. On his return to Cambridge he was appointed Medical Tutor and Lecturer at St John's, and occupied his spare time by translating into English Ziegler's Pathological Anatomy. In 1882 he was appointed Editor of The Practitioner, a post he held for twelve years. He graduated M.D. in 1884, and was elected a Fellow of the Royal College of Physicians of London in 1886 . The following year he was appointed its Goulstonian Lecturer, and later published his lectures on The Nature of Fever. In 1888 he was appointed first Croonian Professor by the College, and delivered a course of lectures on Antipyretics.

In $1889 \mathrm{MacAlister}$ was elected to represent Cambridge University on the General Medical Council in succession to Sir George Humphry on the only occasion when there was a contest for the post. He had the almost unanimous support of the resident members of the medical faculty, and was elected by 194 votes to 139 . He remained a member of the Council, later representing the University of Glasgow, until I933, being President from 1904 to 1931 .

From 1881 to 1907 , the period of his residence in Cambridge, he took a full and active part in the affairs of the Senate and of the College, where 
he was appointed Linacre Lecturer and Tutor. He was elected repeatedly to the Council of the Senate, and for years served as Secretary to that body.

In 1907 MacAlister was chosen by the Crown to succeed Dr Story as Vice-Chancellor and Principal of the University of Glasgow. When he went there he knew little of Scottish academic systems, but within a year he had familiarised himself with the working of Scottish universities, their histories, traditions, and ordinances. He was a great Principal. During his tenure of office over twenty new chairs were established, and the lecturing staff was doubled. The Student Welfare scheme came into being and many new buildings were added. Of all his enterprises, that which lay nearest his heart was the building of the beautiful Memorial Chapel, now one of the chief glories of the University.

When he resigned the Principalship in Glasgow, the University crowned his career by electing him its Chancellor.

MacAlister was an ideal chairman, firm, but always patient and courteous. He had a flair for drafting and understanding ordinances, was quick at seizing points, and amazingly resourceful at finding solutions of difficulties. He undertook and accomplished an astounding amount of work; often done when he was suffering severe pain. He was never strong physically; but his courage and spirit were indomitable, and he held that personal feelings-even pain and extreme weakness-must give way to duty.

He served on the Carnegie United Kingdom Trust, as well as on the Universities' Trust; on the Empire Universities' Bureau; the Imperial College of Science; and on many Commissions, including the Royal Commission on the Civil Service.

MacAlister was created K.C.B. in 1908, and a Baronet in $1924 . \mathrm{He}$ was a Deputy-Lieutenant and a Freeman of the City of Glasgow, and a Justice of the Peace for Glasgow and Cambridge. He received honorary degrees from twelve universities in the British Empire, and one from the University of Athens. Other decorations were those of a Commander of the Legion of Honour, and a Cavalier of the Crown of Italy.

He loved travelling and could tell of adventure in many parts of the world. For languages he had a passion. They were his chief recreation, and his book of translated Echoes is a tour-de-force of bewildering variety.

$\mathrm{He}$ was a man of deep religious faith: a staunch Presbyterian. $\mathrm{He}$ took an active interest in the transfer of Westminster College from London to Cambridge and in the establishment of St Columba's Church there. He served as an elder in St Columba's for over thirty years.

He was elected a Fellow of the Society in 1917 , and died on January 15 , 1934 .

N. W.

P.R.S.E.-VOL. LIV, I933-34, PART III. 